\title{
Feeding behavior of Arabi and Najdi lambs and its relationship with the physiological performance
}

\author{
Waleed Yousif Kassim (D). Tarik Faraj Shawket - Hassan Nima Habib (D) Farhan Theyab Khudhu
}

\author{
WY Kassim - TF Shawket - HN Habib (Corresponding \\ author) \\ Department of Animal Production, College of Agriculture, \\ University of Basrah, Iraq. \\ email: hassan.nima@uobasrah.edu.iq
}

\section{FT Khudhu}

Subsidiary researcher in Animal Farm, College of Agriculture, University of Basrah, Iraq.

Received: September 06, 2019 • Accepted: September 14, 2019 • Published Online: October 16, 2019

\begin{abstract}
This study was conducted to determine the relationship between biochemical, hematological parameters and the feeding behavior in two Iraqi sheep breeds (Najdi and Arabi). The trials were conducted on 12 healthy (6 lambs per breed). Blood samples were collected on days 0 and over 30 of the experiment. The feeding behavior was recorded from 7:00 to 7:30 in the morning daily. The final body weight, average daily gain, daily food consumption, eating time and feed compete were a significant $(P<0.05)$ increase in Najdi lambs in comparison with Arabi lambs. The concentration of cholesterol was a significant $(P<0.05)$ increase in Najdi lambs before and after 30 days of the experiment. Copper concentration was a significant $(P<0.05)$ increase in Najdi blood's as compared with Arabi. Experimental periods observed significantly $(P<0.05)$ differences in serum phosphorus levels. The percentage of Neutrophils cells were decreased significantly $(P<0.05)$ in Najdi lambs in comparison with Arabi before and after the experiment. Serum testosterone hormone concentration was increased significantly $(P<0.05)$ in Najdi lambs in comparison with Arabi, especially at the end of the experiment. Generally, there were no significant $(P<0.05)$ differences observed between two breeds in the daily water consumption, levels of glucose, total protein, albumin, phosphorus, $\mathrm{Fe}$, zinc, and most of the hematological parameters.
\end{abstract}

Keywords: biochemical parameters, productive performance, testosterone hormone

\section{Introduction}

Small ruminant animals such as sheep diffusion in most countries around the world, they play an important role in the local economic agriculture project (Kilgour 1977). In Iraq, sheep normally raised for meat firstly and some time for milk and wool production, both Arabi and Najdi breeds are fat-tailed sheep and reared in semi-arid regions such as the Middle East, they are adaptable to the difficult environmental conditions and also tolerance to the diseases (Eryavuz et al 2007; Alamer and Adel Al-Hozab 2004; Al-Saigh and Al-Qas 1999).

Comfort behavior is one of the important indicators of the welfare and comfort of animals and their ability to adapting to environmental conditions (Metz and Wierenga 1997). For the concept of animal welfare, animals are free to show their natural feeding behavior on posture condition in response to their physiology and environment. Generally, the feeding behavior is important for choosing and selects the best strategies for development and increases the animal's production because of these trails influence on animal performance (Sanon et al 2007). Feeding behavior and feed intake of sheep on different food varies and can affect their production (Abdullah et al 2013). Generally, feeding behavior, especially eating and ruminant is another strong indicator of the health of sheep (Gorgulu et al 2011).

The determine of blood biochemical and is necessary to give information about the animal health problems, additionally, these parameters are used for measurement the heart attack, liver damage and the quality of proteins in the blood (Prisacaru 2014; Tibbo et al 2005). Many factors may influence the hematological and biochemical blood parameters, these factors divide into two kinds: 1) genetic factors including genotype and breed. 2): environmental factors, including age, sex, species, season, nutrition, geographic location and physiological status (Kassim and ALHellou 2018; Onasanya et al 2015; Njidda et al 2014; Prisacaru 2014; Yokus et al 2006; Nazifi et al 2003).

There have been insufficient comparative studies on the feeding behavior of Arabi and Najdi lambs. In stables and consuming the same type of feed ad libitum. Therefore, this 
study was carried out to determine the feeding behavior of Arabi and Najdi and related to physiological performance.

As limited information about the feeding behavior of our local breed of Iraqi sheep. Therefore, this study was carried out to determine how the breed (Arabi and Najdi sheep) and experimental period can affect the biochemical and hematological parameters and related to their feeding behavior.

\section{Materials and Methods}

This study was conducted in the animal field of College of Agriculture, University of Basrah from 1/1/2015 to $30 / 1 / 2015$, to study the behavior of feeding in two sheep breeds (Arabi and Najdi) and the changes in some biochemical and blood parameters during this period. Twelve healthy lambs, aged between 6-7 months old, were divided randomly into two groups (6 lambs per breed). The live body weight at the beginning of the study ranged from $(18.87 \pm 1.16)$ to $(19.05 \pm 2.15) \mathrm{Kg}$ for Arabi and Najdi lambs respectively. During the morning (at 7:00 o clock), each group was housed in the box ( $4 \mathrm{X} 4 \mathrm{~m} 2)$ at least for 30 minutes and provided with the same diet include $74 \%$ wheat bran, $24 \%$ barley and $1 \%$ vitamins and mineral premix (diet was given based on $2 \%$ of body weight). Clean water was ad libitum in each box. The remaining food and water were determined daily to collect the food and water consumption. During that period (30 $\mathrm{min}$.), the feeding behavior observations were taken by direct seeing. The eating time, feed compete and standing time was recorded daily between 7:00 to 7:30 in the morning. Body weight was recorded at the start of the experiment and then every two weeks. The means of maximum and minimum temperatures during the 30 days of the experiment were 16.9 and $11.3{ }^{\circ} \mathrm{C}$ respectively, those temperatures were recorded by using a thermometer. Jugular vein blood samples (10 $\mathrm{ml}$ per animals) were collected before the beginning the experiment and then every 15 days. $2 \mathrm{ml}$ of blood samples kept in anticoagulants plastic tubs, while, $8 \mathrm{ml}$ kept in coagulants tubs. Blood Samples were transported to the laboratory, the hematological parameters were determined directly, while, other samples $(8 \mathrm{ml})$ separated by centrifugation at $3000 \mathrm{rpm}$ for 20 minutes and frozen under $\left(-20^{\circ} \mathrm{C}\right)$ until analysis.

Total white blood cells count (WBCc), white cell differentiation number and red blood cell number (RBC) were measured by using haemocytometer method, whereas, packed cell volume was measured by using hematocrit method. Both methods were described by Schalm (1986). The levels of glucose, cholesterol, total protein, and albumin were measured by using a chemical kit of the Germany Biochemical Company. The levels of phosphorus, Fe, copper and zinc were determined by using a chemical kit of the Egyptian Company for Biotechnology. Testosterone was determined by using a procedure associated with the kit of the Monobind Inc Company - U.S.A.

The observed data were analyzed statistically using the SPSS (2010) software package with one-way analysis of variance. Statistically significant differences were determined by the $P<0.05$ levels of significance. The general statistical model was:

$\mathrm{Y}_{\mathrm{ijk}}=\mu+\mathrm{B}_{\mathrm{i}}+\mathrm{P}_{\mathrm{j}}+\mathrm{BP}_{\mathrm{ij}}+\mathrm{e}_{\mathrm{ijk}}$

where: $\mathrm{Y}_{\mathrm{ijk}}$ is the kth observation of the ith breed, within the jth period. $\mu$ : common mean. $\mathrm{T}_{\mathrm{i}}$ : the effect of the ith breed $(i=2) . P_{j}$ : the effect of the jth period $(j=3) . B_{i j}$ : the effect of the interaction between breed and periods. $\mathrm{e}_{\mathrm{ijk}}$ : the experimental error, randomly and naturally distributed on all observations.

\section{Results and Discussion}

Growth characteristics and feeding behaviors in two sheep breeds were observed in Table 1. The final body weight, average daily gain, daily food consumption, eating time and feed compete were a significant $(P<0.05)$ increase in Najdi lambs in comparison with Arabi lambs. In addition, feed conversion was better in Najdi lambs as compared with Arabi. There were no significant $(P<0.05)$ differences observed between two breeds in the daily water consumption. The increases in final body weight and average daily gain may be due to the genotype, according to Abdulla et al (2013) who study the feeding behavior in two species of animals (goats and sheep) found variation in average daily gain which related with the genotype. There is a relationship between daily food consumption, feed conversion and eating time (Gorgulu et al 2011), when animals spent more time in the eating will lead to stimulating more saliva secretion, and elevate in the amount of food consumed (Carter et al 1990). Whereas, Keskin et al (2010) concluded that the eating behavior increased when the food was available, and they suggested that fed animals in pens (not grazing) allow animals to spend more time in eating. Additionally, the differences in the genotype capacity, body weights and movement activity between Najdi and Arabi lambs might be another reason for the variation in feeding behavior. On the other hand, heavier animals need more amount of food than thinner once, so, based on our data (Table 1) Najdi eating more food as compared with Arabi as a result of their high body weight. These results are compatible with the result of Lebopa et al (2011) who found that the breed had an effect on eating time and standing time either goats are browsed or grazed. In addition, the result agrees with Van Soest (1994). Feed compete behavior is natural biological action during feeding, especially under group feeding management or limited space in pens (Prezivaca et al 2012; Kilgour 1977). 
Najdi was higher statistically in the daily water intake as compared with Arabi sheep. Keskin et al (2005) reported that there is a lineal relationship between dry mater consumption and water intake in small ruminant.

Table 1 Growth characteristics and feeding behavior in two sheep breeds (during $30 \mathrm{~min}$.) (Mean \pm S.E.).

\begin{tabular}{lccc}
\hline \multicolumn{1}{c}{ Parameters } & Arabi & Najdi & $P$-value \\
\hline Initial body weight $(\mathrm{kg})$ & & & 0.278 \\
Final body weight & $18.87 \pm 1.16$ & $19.05 \pm 2.15$ & 0.00 \\
Average daily gain $(\mathrm{g})$ & $21.00 \pm 2.71^{\mathrm{b}}$ & $22.90 \pm 2.00^{\mathrm{a}}$ & 0.00 \\
Daily food consumption $(\mathrm{g})$ & $71.00 \pm 3.66^{\mathrm{b}}$ & $128.33 \pm 3.10^{\mathrm{a}}$ & 0.00 \\
Feed conversion $(\mathrm{g} / \mathrm{g})$ & $574.00 \pm 12.81^{\mathrm{b}}$ & $725.47 \pm 11.87^{\mathrm{a}}$ & 0.00 \\
Eating time (min.) & $8.08 \pm 0.98^{\mathrm{a}}$ & $5.65 \pm 0.92^{\mathrm{b}}$ & 0.00 \\
Feed compete $(\mathrm{No})$. & $25.43 \pm 0.11^{\mathrm{b}}$ & $27.39 \pm 0.09^{\mathrm{a}}$ & 0.00 \\
Daily water intake $(\mathrm{L})$ & $1.53 \pm 0.02^{\mathrm{b}}$ & $2.57 \pm 0.03^{\mathrm{a}}$ & 0.356 \\
\hline
\end{tabular}

The data are shown in Table 2 indicated that the levels of glucose, total protein and albumin did not differ either between breeds or between experimental periods. The concentration of cholesterol was a significant $(P<0.05)$ increase in Najdi lambs before and after 30 days of the experiment. The interaction between period and breed indicated that the level cholesterol dropped from 121.26 \pm 3.96 $\mathrm{mg} / 100 \mathrm{ml}$ before beginning of experiment to $61.52 \pm 2.96$ $\mathrm{mg} / 100 \mathrm{ml}$ in the end of the experiment. Glucose, total protein and albumin levels were not significant differences between breeds or experimental periods, thus means that breed do not effect on these parameters either before or after the experiment. These findings are similar to the reports of Prisacaru (2014), Glowinska and Oler (2013), Kucera and Chladek (2004) in different cattle breeds. The concentration of cholesterol was significant higher in Najdi as compared with Arabi. Prisacaru (2014) suggested that cholesterol is one of some biochemical parameters that effect by breeds in Romania cattle. Whereas, the reason of the dropping of cholesterol level during the end of the experiment may be due to that testosterone hormone was higher significantly in Najdi serum as compared with Arabi (Figure 1), testosterone as steroid hormone is derived from cholesterol (Waterman and Keeney 1992), so, naturally cholesterol level will decrease in the blood to meet the requirements of testosterone synthesis in Leydig cells (Brooks 1975). The values of glucose, cholesterol, total protein and albumin were within normal range in Arabi and Najdi sheep (Kassim and AL-Hellou 2018; Kassim 2017).

Table 2 Effect of the breed and experimental periods on biochemical parameters (Mean \pm S.E.).

\begin{tabular}{|c|c|c|c|c|}
\hline Parameters & $\begin{array}{l}\text { Glucose } \\
\mathrm{mg} / 100 \mathrm{ml}\end{array}$ & $\begin{array}{c}\text { Cholesterol } \\
\mathrm{mg} / 100 \mathrm{ml}\end{array}$ & $\begin{array}{l}\text { Total protein } \\
\mathrm{g} / 100 \mathrm{ml}\end{array}$ & $\begin{array}{l}\text { Albumin } \\
\mathrm{g} / 100 \mathrm{ml}\end{array}$ \\
\hline Experiment periods & \multicolumn{4}{|c|}{0 day } \\
\hline Arabi & $44.44 \pm 3.42$ & $111.21 \pm 3.91^{\mathrm{b}}$ & $5.28 \pm 0.55$ & $3.68 \pm 0.42$ \\
\hline Najdi & $45.12 \pm 6.11$ & $131.31 \pm 4.46^{\mathrm{a}}$ & $6.40 \pm 0.88$ & $4.92 \pm 0.53$ \\
\hline Overall mean & $44.78 \pm 4.50$ & $121.26 \pm 3.96^{\mathrm{A}}$ & $5.84 \pm 0.40$ & $4.30 \pm 0.50$ \\
\hline Experiment periods & \multicolumn{4}{|c|}{30 days } \\
\hline Arabi & $41.12 \pm 3.60$ & $52.71 \pm 0.91^{\mathrm{b}}$ & $5.16 \pm 1.12$ & $4.34 \pm 0.92$ \\
\hline Najdi & $44.06 \pm 3.41$ & $70.33 \pm 4.39^{\mathrm{a}}$ & $7.02 \pm 0.66$ & $3.94 \pm 0.51$ \\
\hline Overall mean & $42.59 \pm 3.26$ & $61.52 \pm 2.96^{\mathrm{B}}$ & $6.09 \pm 1.11$ & $4.14 \pm 0.48$ \\
\hline$P$-value & 0.209 & 0.00 & 0.234 & 0.345 \\
\hline
\end{tabular}

Different capital and small letter within class means significant difference $(P<0.05)$ between periods and breeds respectively.

There was no significant $(P<0.05)$ differences were presented between two breeds in most mineral concentrations such as phosphorus, $\mathrm{Fe}$ and zinc except in copper concentration, which showed a significant $(P<0.05)$ increase in Najdi blood's as compared with Arabi (Table 3).
Experimental periods observed significantly $(P<0.05)$ differences only in serum phosphorus levels, which is raised from $23.58 \pm 3.66 \mathrm{mg} / 100 \mathrm{ml}$ before experiment to $28.74 \pm$ $2.68 \mathrm{mg} / \mathrm{ml}$ at the end of the experiment. The depression in phosphorus level after 30 days of the experiment may be 
explained as follows: both phosphor and calcium are necessary for information the matrix bone and sharing in the skeletal growth, especially in younger animals (Prisacaru 2014), so, such animals need more amount of minerals bones, which take it from blood circulation. Copper concentration was significantly increased in Najdi blood's as compared with Arabi. Samaradzija et al (2011) showed that blood serum mineral concentrations such as $\mathrm{Ca}, \mathrm{P}, \mathrm{Na}, \mathrm{K}, \mathrm{Cl}$ and $\mathrm{Mg}$ are effected by the goat breeds. The values of phosphorous, $\mathrm{Fe}$, copper and zinc were within normal range in Arabi and Najdi sheep (Kassim and AL-Hellou 2018; Kassim 2017).

The data in Table 4 indicated that no significant $(P<$ $0.05)$ differences were observed between breeds or experimental periods in most hematological parameters except in Neutrophil cells. The percentage of Neutrophils cells were decreased significantly $(P<0.05)$ in Najdi lambs in comparison with Arabi before and after the experiment. Hematological parameters do not affect by breed or experimental periods, so, there is no any negative changes in blood hematological, which are considered as an index for the activation of the metabolic processes and the health of the animal's body. Generally, the ratio of $\mathrm{L} / \mathrm{N}$ does not differ between two breeds, which means that animals did not suffer from any stress conditions during the experiment. However, the value for Neutrophil was higher for Arabi lambs in comparison with Najdi that means that Arabi was more suffer from stress, may be as a result of the environmental conditions or housed (Coles 1980). This result agrees with Njidda et al (2014) in Nigeria sheep breeds. The values of hematological parameters in the present study are falling within the normal range reported in sheep (Njidda et al 2014; Baneejee 2007; Campbell et al 2003).

Table 3 Effect of the breed and experimental periods on some mineral concentrations (Mean \pm S.E.)

\begin{tabular}{|c|c|c|c|c|}
\hline Parameters & $\begin{array}{l}\text { Phosphorus } \\
\text { mg/100ml }\end{array}$ & $\begin{array}{c}\mathrm{Fe} \\
\mathrm{mg} / 100 \mathrm{ml}\end{array}$ & $\begin{array}{c}\text { Copper } \\
\mu \mathrm{g} / 100 \mathrm{ml}\end{array}$ & $\begin{array}{c}\text { Zinc } \\
\mu \mathrm{g} / 100 \mathrm{ml}\end{array}$ \\
\hline Experiment periods & & & & \\
\hline Arabi & $22.04 \pm 3.16$ & $1.16 \pm 0.15$ & $89.07 \pm 9.84^{b}$ & $35.90 \pm 3.51$ \\
\hline Najdi & $25.13 \pm 3.7$ & $1.54 \pm 0.11$ & $134.59 \pm 8.15^{\mathrm{a}}$ & $35.14 \pm 4.09$ \\
\hline Overall mean & $23.58 \pm 3.66^{\mathrm{B}}$ & $1.83 \pm 0.10$ & $111.8 \pm 4.18$ & $35.52 \pm 3.63$ \\
\hline Experiment periods & & & & \\
\hline Arabi & $28.44 \pm 2.48$ & $2.04 \pm 0.05$ & $62.35 \pm 21.09^{\mathrm{b}}$ & $3.79 \pm 36.79$ \\
\hline Najdi & $29.03 \pm 2.25$ & $2.13 \pm 0.01$ & $127.26 \pm 14.47^{\mathrm{a}}$ & $25.61 \pm 3.14$ \\
\hline Overall mean & $28.74 \pm 2.68^{\mathrm{A}}$ & $2.08 \pm 0.06$ & $94.80 \pm 16.41$ & $31.29 \pm 3.22$ \\
\hline$P$-value & 0.00 & 0.328 & 0.00 & 0.278 \\
\hline
\end{tabular}

Table 4 Effect of the breed and experimental periods on hematological parameters (Mean \pm S.E.).

\begin{tabular}{|c|c|c|c|c|c|c|}
\hline Parameters & $\begin{array}{c}\text { RBC } \\
\left(10^{6} / \mathrm{ml}\right)\end{array}$ & $\begin{array}{l}\text { PCV } \\
(\%)\end{array}$ & $\begin{array}{c}\text { WBC } \\
\left(10^{3} / \mathrm{ml}\right)\end{array}$ & $\begin{array}{c}\mathrm{L} \\
(\%)\end{array}$ & $\begin{array}{c}\mathrm{N} \\
(\%)\end{array}$ & $\begin{array}{l}\mathrm{L} / \mathrm{N} \\
(\%)\end{array}$ \\
\hline Experiment periods & & & & & & \\
\hline Arabi & $\begin{array}{c}8.70 \\
\pm 1.41\end{array}$ & $\begin{array}{c}23.70 \\
\pm 1.04\end{array}$ & $\begin{array}{c}5.18 \\
\pm 1.80\end{array}$ & $\begin{array}{c}55.2 \\
\pm 1.23\end{array}$ & $\begin{array}{l}40.9^{\mathrm{a}} \\
\pm 2.30\end{array}$ & $\begin{array}{c}1.34 \\
\pm 0.08\end{array}$ \\
\hline Najdi & $\begin{array}{c}8.91 \\
\pm 2.24\end{array}$ & $\begin{array}{l}24.21 \\
\pm 1.11\end{array}$ & $\begin{array}{c}5.58 \\
\pm 1.13\end{array}$ & $\begin{array}{c}61.1 \\
\pm 1.00\end{array}$ & $\begin{array}{l}37.8^{\mathrm{b}} \\
\pm 1.3\end{array}$ & $\begin{array}{c}1.61 \\
\pm 0.06\end{array}$ \\
\hline Overall mean & $\begin{array}{c}8.80 \\
\pm 1.75\end{array}$ & $\begin{array}{l}23.95 \\
\pm 1.81\end{array}$ & $\begin{array}{c}5.38 \\
\pm 2.78\end{array}$ & $\begin{array}{c}58.1 \\
\pm 2.60\end{array}$ & $\begin{array}{l}39.35 \\
\pm 2.51\end{array}$ & $\begin{array}{c}1.47 \\
\pm 0.03\end{array}$ \\
\hline Experiment periods & & & & & & \\
\hline Arabi & $\begin{array}{c}7.44 \\
\pm 0.36\end{array}$ & $\begin{array}{l}25.40 \\
\pm 0.87\end{array}$ & $\begin{array}{c}5.03 \\
\pm 1.06\end{array}$ & $\begin{array}{l}51.3 \\
\pm 2.2\end{array}$ & $\begin{array}{l}41.8^{\mathrm{a}} \\
\pm 1.98\end{array}$ & $\begin{array}{c}1.22 \\
\pm 0.03\end{array}$ \\
\hline Najdi & $\begin{array}{c}8.89 \\
\pm 1.81\end{array}$ & $\begin{array}{l}26.40 \\
\pm 0.33\end{array}$ & $\begin{array}{c}4.86 \\
\pm 1.37\end{array}$ & $\begin{array}{l}55.8 \\
\pm 1.9\end{array}$ & $\begin{array}{l}37.7^{\mathrm{b}} \\
\pm 2.57\end{array}$ & $\begin{array}{c}1.50 \\
\pm 0.05\end{array}$ \\
\hline Overall mean & $\begin{array}{c}8.16 \\
\pm 1.81\end{array}$ & $\begin{array}{l}25.90 \\
\pm 1.67\end{array}$ & $\begin{array}{c}4.94 \\
\pm 2.37\end{array}$ & $\begin{array}{c}53.5 \\
\pm 1.25\end{array}$ & $\begin{array}{c}39.7 \\
\pm 1.14\end{array}$ & $\begin{array}{c}1.36 \\
\pm 0.03\end{array}$ \\
\hline$P$-value & 0.388 & 0.211 & 0.245 & 0.365 & 0.00 & 0.321 \\
\hline
\end{tabular}

Different capital and small letter within class means significant difference $(P<0.05)$ between periods and breeds respectively.

L: Lymphocytes. N: Neutrophils. L/N: Lymphocytes/Neutrophils. 
Serum testosterone hormone concentration was increased significantly $(P<0.05)$ in Najdi lambs in comparison with Arabi, especially at the end of the experiment (Figure 1). The mean values ranged from $2.21 \pm 0.11$ to $4.81 \pm 0.13 \mathrm{ng} / \mathrm{ml}$ for Arabi lambs and from 3.01 \pm 0.17 to $7.11 \pm 0.23$ for Najdi lambs before and after 30 days of experiment respectively. Testosterone concentration was higher in Najdi blood as compared with Arabi especially, in the end of the experiment. According to Abdel-Hafez (2002) testosterone secretion depends on the animal's genetic ability and their scrotum circumference. Generally, Najdi rams have bigger testes as compared with Arabi once (Al-Asadi 2017). This result is similar to the result of Tajangookeh et al (2007) in three breeds of Iranian fat-tailed rams.

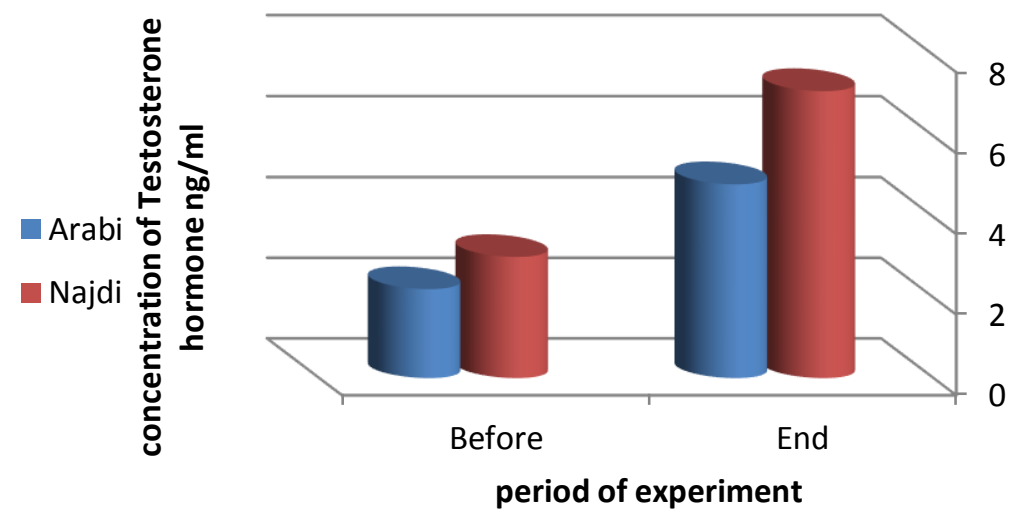

Figure 1 Effect of the breed and experimental periods on testosterone.

\section{Conclusions}

From our data, it could be suggested that Arabi lambs (when housed in pens) are less on food consumption, which reflex negatively on final body weight, average daily gain and food conversion in comparison with Najdi lambs. On the other hand, Najdi sheep spent more time in eating and less time in standing. Therefore, Najdi breed is better than Arabi breed when rearing as groups holding management. Furthermore, the breed has an effect on the concentrations of the biochemical metabolic and hematological parameters may be due to the variation in activity between breeds.

\section{Acknowledgments}

The authors are grateful to Dr. Wessam Monther Mohammed Saleh College of Veterinary Medicine, University of Basrah. In addition, we give our thanks to all the people who help us specially, the workers in the Animal Field.

\section{Conflict of Interest Statement}

We confirm that we have no conflicts of interest.

\section{References}

Abdel-Hafez MAM (2002) Studies on reproductive performance in sheep. Ph.D. Thesis, Faculty of Agriculture, Zagazig University, Zagazig Egypt.

Abdullah NM, Baber ME, Abdul jabbar M, Bahtti JA (2013) Feeding behavior, voluntary intake and digestibility of various summer fodders in sheep and goats. Pakistan Journal of Zoology 45:53-58.
Alamer M, Adel Al-Hozab N (2004) Effect of water deprivation and season on feed intake, body weight and thermoregulation in Awassi and Najdi sheep breeds in Saudi Arabia. Journal of Arid Environments 59:71-84.

Al-Asadi FA (2017) Effect of adding some amino acid and Beet juice to the dilutors on some cooling and freezing rams semen trails. Ph.D. Thesis, College of Agriculture, University of Basrah, Iraq.

Al-Saigh MNR, Al-Qas JA (1999) Sheep and Goats Production. In: Chapter II: The Breeds of Sheep and Goats and the Classification Methods, Dar Alhakma-University of Basrah, pp. 27-52.

Baneejee GC (2007) A Textbook of Animal Husbandry. 8th Ed. Published by Raju Primlani for Oxford and IBJ publishing Co. PVT Ltd, New Delhi, pp. 1079.

Brooks RV (1975) Androgens. Journal of Clinical Endocrinology \& Metabolism 4:503-520.

Campbell JR, Kenealy MD, Campbell KE (2003) Animal Science. The Biology, care and Production of Domestic Animals. McGraw Hill US, Pp. 510.

Carter RF, Allen OB, Grovum WL (1990) The effect of feeding frequency and meal size on amounts of total and parotid saliva secreted by sheep. British Journal of Nutrition, 63: 305-318.

Coles EH (1980) Veterinary Clinician Pathology 3rd. Edn. W.B. Sanders Co. Philadelphia, pp. 10-20.

Eryavuz A, Avci G, Kucukkurt I, Fidan AF (2007) Comparison of plasma leptin, insulin and thyroid hormone concentrations and some biochemical parameters between fat-tailed and thin-tailed sheep breeds. Revue de Médecine Vétérinaire 158:244-249.

Glowinska B, Oler A (2013) Biochemical and hormonal characteristics of peripheral blood in bulls in relation to genotype. FoliaBiologica (Kraków) 61:73-77.

Gorgulu M, Boğa M, Sahinler S, Kilic U, Darcan, N (2011) Meal criterion and feeding behaviour in sheep and goats. Challenging 
strategies to promote the sheep and goat sector in the current global context. Options Méditerranéennes 99:31-34.

Kassim WY (2017) The effect of vitamin E and PMSG treatment during breeding season on some biochemical parameters and reproductive trails for two breeds of sheep. Basrah Journal of Agricultural Sciences 30:83-90.

Kassim WY, AL-Hellou MF (2018) Effect of geographic location and age on levels of some biochemical parameters of ewes in Southern of Iraq. Journal of Biosciences and Medicines 6:21-29.

Keskin M, Sahin A, Gul A, Bicer O (2010) Effects of feed refreshing frequency on behavior responses of Awassi lambs. Turkish Journal of Veterinary and Animal Sciences 34:333-338.

Keskin M, Pahun A, Bicer O, Gul S, Kaya P, Sari A, Duru M (2005) Feeding behaviour of Awassi sheep and Shami (Damascus) goats. Turkish Journal of Veterinary and Animal Sciences 29:435-439.

Kilgour R (1977) Design sheep yards to suit the whims of sheep. New Zealand Farmer 98:29-31.

Kuera J, Chladek G (2004) The effect of year, season, breed and reproduction cycle on some plasma parameters in cows and heifers. Zesz. Nauk. AR Wrocaw, Zoot 501:149-155.

Lebopa CK, Boomker EA, Chimonyo M, Mulugeta SD (2011) Factors affecting the feeding behaviour of free ranging Tswana and Boer goats in the False Thornveld of the Eastern Cape, South African Journal of Science 8:70-80.

Metz J, Wierenga H (1997) Behavioural criteria for design of housing systems for cattle. Cattle Housing systems, Lameness and Behaviour. Martinus Nijhoff Publishers, Boston, MA, U.S.A.

Nazifi S, Saeb M, Rowghani E, Kaveh K (2003) The influences of thermal stress on serum biochemical parameters of Iranian fat-tailed and their correlation with Triiodothyronine, Thyroxin and Cortisol concentrations. Comparative Clinical Pathology 12:135-139.

Njidda AA, Shuai'bu AA, Isidahomen CE (2014) Haematological and serum biochemical indices of sheep in semi-arid environment of northern Nigeria. Global Journal of Science Frontier Research 14:49-56.

Onasanya GO, Oke FO, Sanni TM, Muhammad AI (2015) Parameters influencing haematological, serum and biochemical references in livestock animals under different management systems. Open Journal of Veterinary Medicine 5:181-189.
Prezivaca PDM, Altincekic SO, Koyuncu M (2012) Small ruminant behaviour and welfare. Krmiva 54:205-216.

Prisacaru AE (2014) Effects of age, sex and breed on biochemical blood parameters of cattle at slaughterhouse. Lucrări Ştiinţifice Seria Zootehnie 62:164-168.

Samardzija M, Dobranic T, Lipar M, Harapin I, Prvanovic N, Grizelj J, Gracner G, Dobranic V, Radisic B, Duricic D (2011) Comparison of blood serum macromineral concentrations in meat and dairy goats during puerperium. Journal Veterinarski Arhiv 81:1-11.

Sanon HO, Kabore-Zoungrana C, Ledin I (2007) Behaviour of goats, sheep and cattle and their selection of browse species on natural pasture in a Sahelian area. Small Ruminant Research 67:64-74.

Schalm OW (1986) Veterinary Haematology. Lea and Febiger, Philadelphia. U.S.A. pp. 1-1221.

SPSS (2010) Statistical Packages of Social Sciences. Version 9.0.

Tajangookeh HD, Shahen AZ, Ahahrebabak MS, Malek S (2007) Monthly variation of plasma concentration of testosterone thyroid hormones and reproductive characteristics in three breeds of Iranian fat-tailed rams throughout one year. Pakistan Journal of Biological Sciences 10:3420-3424.

Tibbo M, Aragaw K, Abunna F, Woldemeskel M, Deressa A, Lemma D, Rege LEO (2005) Factors affecting haematological profiles in three indigenous Ethiopian sheep breeds. Comparative Clinical Pathology 13:119-127.

Van Soest PJ (1994) Nutritional ecology of ruminant. 2ed Ithaca: Cornell University Press, pp. 476.

Waterman MR, Keeney DS (1992) Genes involved in androgen biosynthesis and the male phenotype. Hormone Research 38:217221.

Yokus B, Cakir DU, Kanay Z, Toprak G, Uysal E (2006) Effects of physiological variations on the serum chemistry, vitamins and thyroid hormone concentrations physiological variations on the serum chemistry, vitamins and thyroid hormone concentrations in sheep. Journal of Veterinary Medicine 53:271-276. 